\title{
Niger Delta Crises and the Way Forward: A Study of the Mood System in Helon Habila's Novel, Oil on Water
}

\author{
Edokpayi Justina N. Ph.D \\ Ambrose All University, Ekpoma, Edo State, Nigeria
}

\begin{abstract}
The Niger delta of Nigeria has been besieged by a lot of crises, which have posed serious security risks to the region. This has adversely and seriously affected not only the region, but Nigeria in general. The processes of crude oil extraction in the Niger delta have resulted in ecological degradation and oil pollutions, thereby doing a lot of damages to the farmlands and fishing waters of the people, whose major occupations are farming and fishing. Petroleum, the main source of Nigeria's revenue is obtained in the Niger delta. Yet, Deltans are confronted with a lot of problems; they are impoverished, exploited, neglected and marginalized despite the economic value of the region to the Nigerian economy. No serious or commensurate efforts are made by the government or the multinational oil companies operating in the region to compensate the people for the losses they suffer through oil pollutions. This has resulted in a lot of protests and violence, culminating in the social unrest in the region. To this effect, there have been reactions to the crises in diverse ways. Though such efforts have yielded little dividends, the crises have persisted. Niger delta deserves priority attention in terms of human and infrastructural developments. In the literary circle, some Nigerian literary artists have expressed concern over the issue with a view to creating awareness on the seriousness of the crises, and advancing suggestions that will proffer permanent solutions to the problems. This paper examines and expounds how Helon Habila deploys the mood system as a language tool in his novel, Oil on Water, to address the Niger Delta crises. He advances suggestions to put an end to the crises in order to restore peace, and enhance sustainable development in Nigeria.
\end{abstract}

Keywords: Petroleum; Niger delta; Crises; Oil pollution; Solutions.

(ㄷ) (1) CC BY: Creative Commons Attribution License 4.0

\section{Introduction}

Petroleum, the most valuable mineral product in the world is obtained in abundance in the Niger delta region of Nigeria. But, unfortunately, the region is denied the benefits of petroleum and the priority attention it deserves in terms of infrastructural and human developments. Not only does the region suffer ecological degradation that poses threats to lives and properties, but the people who have become victims of environmental pollutions are subjected to abject poverty and untold hardship in the midst of plenty. The wealth accruing to Nigeria from petroleum has been diverted by the corrupt leaders to the detriment of the South, Nigeria's major source of revenue. Moreover, southerners are exploited, neglected and marginalized by the various oil companies operating in the region and the government. The injustice meted out to the people triggered a lot of protests and violence from different quarters.

The Niger Delta region has been besieged by a lot of crises ranging from protests, violence, militancy to youth restiveness that have culminated in social unrest. The nagging problem of militancy, a burning issue in Nigeria, is consequent upon the injustice meted out to the Niger Deltans. Despite the adverse effects of the crises on the people, the Nigerian economy and the world oil market, the government and the oil companies are unable to proffer permanent solutions to the crises.

Generally, due to the adverse effects of man's industrial activities all over the world, the attention of the literary artists is gradually shifting to the issue of ecological crisis. In different parts of the world, eco-criticism, a literary theory is becoming popular in literature. Eco-criticism is the "study of literature and the environment from an interdisciplinary point of view where all sciences come together to analyze the environment and brainstorm possible solutions for the correction of the contemporary environmental situation" (Lawrence Buck 288). In the same vein, Jude Agho claims that eco-criticism is a revolutionary movement concerned with the despoliations of the flora and fauna of the ecosystem, owing to the industrial activities all over the world and the adverse effects on man (287). Agho further claims that the idea underscores the application of ecology and ecological concepts to the study of literature. The movement is a contribution to the efforts to resolve the world ecological crisis that threatens human existence.

The seriousness of the Niger delta crises in Nigeria has been a source of concern that has attracted public attentions, especially from the literary circle in Nigeria by artists such as Ken Saro-wiwa, Tanure Ojiade, Kaine Agary and Helon Habila. Habila's novel, Oil on Water, is preoccupied with the ecological degradation in the Niger delta region, the devastating effects on the people, corruption in Nigeria, neglect of the people, and the resultant social unrest. The author X-rays the destruction done to the Niger Delta region due to the processes involved in oil extraction by the various oil companies.

This paper examines and explicates how Helon Habila deploys the mood system, among other language resources to convey the themes of his novel under study. Moreover, he advances suggestions aimed at proffering 
lasting solutions to the problems. In language study, mood reveals the various functions of speeches. How the intention of a speaker is determined in a given situation in a text is the concern of mood. Jayanthi Murthy claims that "mood is the mode or method in which a verb is used to express a particular action (95). Micheal Halliday who defines mood as that aspect of grammar that indicates the roles of characters in a text, further asserts that:

Language itself defines the roles which people may take in given situations in which they are communicating with one another, and incorporates options whereby the speaker can vary his own communication role, making assertions, asking questions, giving orders, expressing doubts and so on. The basic 'speech functions' of statements, questions, responses, commands and exclamations fall within this category. (159)

The moods in a literary text are generally significant in the realization of the author's style of narration. In this study, we examine how Habila applies various moods in giving texture to his story, taking cognizance of the fact that each category of the English sentence, serves a purpose that is determined by contextual variations.

\section{The Mood System}

Michael Halliday sees mood as that aspect of the interpersonal function of language, indicating the speech roles that characters adopt in their desire to communicate. The role may be that of declaring, questioning, commanding and exclaiming. Here are some of the functional sentence types the author deploys to communicate the themes of $\mathrm{Oil}$ on Water, his novel, under consideration.

\subsection{Declarative Sentences}

Declarative sentences make statements or assertions or state facts that cannot be doubted (A. W. Heffernan and John Lincion). We examine below Helon Habila's use of declarative sentences with their informative nature in the text to convey his messages.

1. Their rivers were already polluted and useless for fishing, and the land grew only gas flares and pipelines.(40)

2. It was an entire village on stilt, situated by the river on a vast mud flat which at that time was under water... The houses were made from weeping-willows bamboos and raffia palms bits of zinc and plywood and clock and it seemed anything else the builders were able to lay their hands on. The whole scarecrow settlement looked as if the next strong wind or wave would blow it away.(14)

Habila deploys the declarative construction in extract 1 above to convey the theme of oil pollution in the Niger delta. He paints a clear picture of the damages done to the fishing water and farmlands of a people whose major occupations are fishing and farming. The consequence is that their occupations are hindered, thereby plunging them into unemployment, which is responsible for abject poverty, hardship, diseases and deaths among the people.

In the same vein, the author portrays the poor, deplorable and dehumanizing environments of the Niger Deltans, especially those who live in the creeks. In sample 2, he describes vividly the deplorable environments, and the poor quality houses in which they live.

Habila also captures the pitiable conditions of the people and the alarming rate of poverty among them. Due to their impoverishment, arising from unemployment as earlier stated, they cannot meet their daily needs. Even the petroleum products obtained in their region such as kerosene, diesel, cooking gas and fuel are unaffordable because they are so expensive and, therefore out of the reach of the people faced with abject poverty.

Despite the wealth accruing from petroleum obtained in their region, Deltans are denied the necessities of life. They lack good medical care, electricity, good drinking water, and job opportunities for their teeming youths. Moreover, their children are denied quality education because their parents cannot afford it. Rufus, a newspaper reporter, whose family has suffered such a fate, narrates his ugly childhood experiences in a Niger delta community. He recalls how they have been forced to sell crabs even at tender age to pay their school fees because of their father's inability to sponsor them in school in the declarative sentences in the excerpt below:

... I picked up pen and paper and the words had come effortlessly. I wrote about our childhood,

about our days catching crabs to pay our way through secondary school, about Boma's dream of becoming a doctor. (127)

Habila also portrays the total neglect of the Niger delta and the people of the region by the government and the oil companies in the text under study. They neither pay the people adequate compensations nor the attention they deserve, in spite of the losses they suffer from the pollution of their land and water. As people of the oil producing region in Nigeria, Deltans deserve the benefits of petroleum as obtained in other counties of the world. Government and the oil companies ought to give the Niger delta and the people priority attention in terms of infrastructural and human developments respectively. Yet, there are no meaningful developments in the region. Habila captures the pitiable situation in the region and the major causes of the Niger delta crises in the excerpt below:

But I don't blame them for wanting to get some benefits out of the pipelines that have brought nothing but suffering to their lives licking into the rivers and wells, killing the fish and poisoning the farmlands. And all they are told by the oil companies and the government is that the pipelines are there for their own good, that they hold great potent for them for their future. These people endure the worst conditions of any oil producing community in the world, the government knows it but does not have the will to stop it, the oil company knows it, but because the government does 
not care, they too don't care. And you think the people are corrupt? No, they are hungry and tired.

Corruption and bad governance are responsible for all the problems in the Niger delta. Only the privileged few in the country enjoy the wealth accruing from petroleum, to the detriment of the Niger Deltans, who have nothing to show for their losses from oil pollutions. This is the height of injustice done the people, and it is the cause of the Niger delta crises. It has forced the Deltan youths into a lot of criminal practices, violence and protests, which have culminated in militancy, a security risk in the Niger delta.

The intervention of the government by the deployment of soldiers to the region has worsened the situations of the people. The incessant clashes between the militants and the soldiers drafted into the region have posed serious problem of insecurity to the region. Their villages are attacked and the people are subjected to terrorisms, harassments, and all forms of inhuman treatment and even deaths. The clashes result in the destruction of lives and properties. Habila gives vivid accounts of the horrible situations in Niger Delta, with the presence of the soldiers and militants who parade the waters, and perpetuate injustice on the innocent and helpless villagers in the extracts below.

1. A man run out of a hut and came face to face with a soldier; he raised his hands high in surrender, as in a single motion, the soldier revised his rifle and swung the butt at the man's head. The man fell back into the doorway and the soldier moved on to another target. (12)

2. The boy grabbed tightly on to my arm, screaming for his father. I saw a gun rise and descended on the old man's head and he slumped against the boat and then into the water. Slowly I stood up, my hands raised. (197)

The authorial voice also narrates the bitter experience of Karibi, a villager in the hands of the soldiers, as he is falsely accused of fraternizing with the militants:

We went to the riverbank with the villagers to watch the speed

boats that brought the soldiers ... Karibi sat between two soldiers, his hands tied behind him, his face staring into the distant horizon.

His son said he'd been taken to Port Harcourt, where he'd be tried and found guilty of fraternizing with the militants. ---But he's innocent. (13)

He also deploys the declarative constructions in the extracts below to reiterate the states of chaos, fear, killings, as well as insecurity to which Niger Deltans are subjected due to the clashes in the oil producing communities.

1. As we talking the professor came in, with only two men. The

rest, he said, they had been killed in the fight with the

soldiers. He was wounded but wouldn't sit. (132)

2. There was a loud noise as of stampeding feet, dust rose and

covered the tight passages, and the stalls and the sheds, people

rushed down the passages, knocking down tables and the

entire sheds as they went. Then a single gunshot ran out.

Then a single moment everyone froze. (11)

Habila reveals cases of incessant kidnappings and states of uncertainty in the Niger delta. As depicted by the author in the novel, many of the youths who claim to be freedom fighters, fighting for the interests of the people have turned militants, kidnappers and terrorists. The different kidnapping groups including the Black Belts of Justice, the Free Delta Army and the AK 47 Freedom Fighters kidnap innocent and helpless people and oil workers, especially the expatriates as reported in these excerpt:

1. People like the professor are responsible for that, they call

themselves freedom fighters, but they are rebels, terrorists

and kidnappers. (26)

2. Now, I saw how thin she looked. Her hair had been chopped off.

Her face was covered within rashes; her skin was slightly discolored from

whatever dye she had used to disguise herself while making her escape

from her kidnappers. (186- 187)

3. Well, just now, on that radio, it was announced they kidnapped

a three-year old girl in Port Harcourt, and you know what, her

family is not connected to the oil industry. A three-year old girl.

They don't care if they are shot. ...It's my job to pursue them to

their swamp hideouts. I capture them and most times, it's

easier to shoot them than to capture them.(148)

Habila paints a clear picture of the state of the kidnapped British woman, Isabel, held hostage by the kidnappers in the creeks. As reported in sample 2, she has been so traumatized that she has become so thin. Sometimes, the victims of the kidnappers lose their lives in the process. Boasting of their destructive activities in the Niger Delta, Professor, the dreaded militant leader says:

... but I can tell you the war is just starting. We will make it so hot

for the government and the oil companies that they will be forced

to pull out. (220).

Due to the incessant kidnappings and deaths of oil workers in Port Harcourt and Warri, which pose security risks, majority of the expatriate oil workers have left Nigeria. Moreover, many of the oil companies have been forced 
to fold up. This has been seriously and adversely affecting not only Nigeria and the economy, but the world oil market.

Moreover, the author conveys the theme of homelessness among the Deltans due to violence. He condemns in totality the violent activities that have rendered many people homeless, thereby forcing them out of their communities in the following samples.

1. ----The doctor can tell you about the deserted villages around here.

They used to be well populated, you know, striving. Now the people

have all packed their things and left, because of the violence. (26)

2. Communities like this had borne the brunt of the war, caught

between the militants and the military. The only way they could

avoid being crushed out of existence was to pretend to be deaf

3 . The place looked desolate. The only signs that a community once

lived there was a few sticks jutting out of the water, pieces of

straw from roof thatches scattered in the mud and pile of

garbage under a tree, that was all. (185).

Cases abound in the novel where many villages have been set ablaze by the reckless soldiers during clashes and in anger against the villagers. The authorial voice narrates his experience in one of such communities with the informative nature of the extract below:

Now it was deserted: the people, with their chickens and pots and

pans, must have escaped ripple down the river in their dugout canoes after

the first shot was fired. Trees lay on the ground, cut in half, dripping vital

sap. The smell of burning hung in the air. In the centre of a compound a hut

had been hit square on its conical roof, causing the thatch to cave in, and

now the grass and the rafters all lay in a big pile of ash in the middle of

the hut.(71)

The messages inherent from the excerpts above are the consequences of the violence and clashes in the region, which are that houses are destroyed, villages are wiped out of existence and the people are rendered homeless.

Habila condemns the mismanagement and corruption in Nigeria. Nigeria is blessed with both human and natural recourses. But the people are subjected to abject poverty and untold hardship by the corrupt leaders, who amass wealth to the detriment of the citizens. He asserts that Nigeria would have been one of the best and most developed countries of the world, but for corruption, which is responsible for poverty and underdevelopment in the sample below:

This segment was accompanied by a long, rote-like voice-over about poverty in Nigeria, and how corruption sustained that poverty, and how oil was the main source of revenue, and how because the country was so corrupt, only a few had access to that wealth. Such great potential. You people could easily become the Japan of Africa, the USA of Africa, but the corruption incredible.(96- 97)

Another form of insecurity which Helon Habila captures in the novel is the risks some Deltans are subjected to in their attempts to find their daily bread. Deprived of their means of livelihood and neglected, Niger Deltans resort to bursting oil pipes lines to siphon fuel, thereby endangering their lives. In the process, a lot of their houses are razed down by fire, and sometimes lives are lost. There have been cases of fire incidents as a result of illegal petrol businesses in the region, where jericans and drums of fuel are stored in residential houses at the risk of the people's lives. Even children are involved in this illegal business. Narrating his experience in his father's house, the authorial voice says:

Even before he opened the door I could smell petrol, and when he turned on the light I saw more than ten drums... We sat on two wooden stools in a clear space between two drums. In the two days I spent at home before returning to Port Harcourt, I saw how much my father has changed. He left home early in the morning in a pickup trucks to go to the bush, where he and his partner buy the petrol from the kids and he return home only after midnight, often drunk. The house stank of petrol and cigarette He said he smoked just to kill the smell. (64)

The unfortunate and horrible Jesse incident of 1985 where many lives were lost was the result of such illegal fuel business. To prevent future reoccurrences of such incidents, the authorities concerned should put security measures in place.

Again, the author conveys the theme of health hazards leading to diseases and deaths in the oil producing communities as a result of injustice. Due to environmental pollution and the presence of toxins in the area that pose risks to lives, the people are exposed to diseases and deaths. It is most pathetic and surprising that neither the oil companies nor the government puts adequate measures in place to protect the lives of the people. When cases of diseases and casualties are reported, nothing is done to save the situation, leaving the people to die like fowls as Habila portrays in the following excerpt.

I told them of the dangers that quenchless flare, but they wouldn't

listen. And a year later, when the livestock began to die and the plants began to wither on their stalk, I took sample of the drinking water and in my lab I measured the level of toxin in it: it was rising steadily. In one year it has grown almost twice the safe level... When I conf ronted the oil workers, they offered me money and a job. ... So when people started dying, I took blood samples and recorded the toxins in them, and this time I sent my result to the government. They thanked 
me and dumped the result in some filing cabinet. More people died... Almost overnight I watched the whole village disappear just like that. (14)

This is a case of injustice that must be corrected to protect the lives of the people. Generally, the authorities have to change their attitudes towards the people of the Niger delta if they want their co-operation.

\subsection{Imperative Sentences}

A verb which is used to express a command, an advice or an entreaty is known as an imperative mood (Murthy 95). It is important to state that in grammar, the subject 'you' is omitted in imperative mood. We observe a prominent use of imperative sentences in the text as Habila conveys the incessant cases of violence, harassment and terrorism to which the innocent and helpless villagers are subjected in Niger Delta. The soldiers and militants order the innocent villagers around indiscriminately, accusing them falsely of one offense or the other. Let us examine the extracts below.

1. Bring her here. Now! (196)

2. ----You, come with us. (12)

3. ----Oya, move faster now! (75

4. ----Stop and throw away your oars and weapons. Do it.

Now... You will do as I tell you. If you attempt to escape, or

disobey in any way, you will be shot. Leave your boat and swim

over to our boat. Do not take anything from your boat. (43)

5. When I tried to explain to a sergeant that Zaq was not feeling well,

he raised his gun at me. (187)

6. ---Keep walking. (45)

7. Just before I turned to see what he found so arresting, I heard

the command:

---Oya, move faster!

8. Perhaps he can tell you about the white woman. Hey, you, talk to the

reporters. Go on. Talk.

---I have to see the professor. I'm a reporter---

---Go back before I blast you to hell! (202)

All the extracts above are instances of Habila's deployment of imperative sentences in the novel to depict forcefulness, the violence, terrorism and harassment to which people in the Niger delta are exposed due to the activities of the kidnappers, militants and soldiers. In extract 1, all the occupants of the boat including the abducted British woman who has escaped from her abductors, are harassed by the kidnappers. This is in an attempt by the owner of the boat to help the British woman to Port Harcourt for safety. As the kidnappers threaten to shoot them, she surrenders herself to them.

Similarly, in sample 8, the journalists in search of the British woman are harassed and ordered around. Just like others in the extracts above, they are subjected to traumatic experiences being commanded by masked kidnappers, with their hands raised above their heads and guns pointed at them as conveyed in the extract.

\subsection{Interrogative Sentences}

An interrogative sentence is a sentence that asks a question. Below are instances of Helon Habila's deployment of interrogative sentences to convey the themes of his text under study.

1. How can Oga do this to me? ... I respected him. I trusted him, and see what

he did to me. Why? I want to know why, can you please tell me? (192)

2. Where is the British woman ... and the professor? (129)

3 . But what do you think? Is she alive or not... Did Zaq give you any

message for me? (96)

4. Are you happy here?

5. I say how can we be happy when we are wanders without a home?

6. What of the people? (157)

In the novel, the author also conveys the themes of betrayal and injustice done to delta youths. With the interrogative sentence in extract 1 above, he reveals Salomon's bitterness against Mr Floode, his expatriate boss, for impregnating and taking away from him his fiance, Koko. Mr. Floode succeeds in luring Koko due to Salomon's poverty. Salomon is poor because as a university graduate he is forced to take up a menial job as a common driver with meager salary. His poverty is, therefore borne out of unemployment, a general problem among Delta youths. This is due to the neglect of the region and its teeming youths by the government and the oil companies, which is responsible for youth restiveness in the region.

Being bitter and traumatized by the betrayal of his boss, Salomon is easily convinced by the suggestion of his friends to kidnap Mrs. Floode in order to collect ransom from her husband, as his punishment for the betrayal. The message inherent in this extract is that some of the youths in Niger Delta take to kidnapping not only to make money, but as a way of retaliating for the injustice done them. Many graduates among them are forced by circumstances to take up menial jobs as cleaners and company drivers. Hear what the authorial voice says about Salomon like many other graduates:

Today he spoke grammatically faultless English, even the assent was modified, easy to understand. Later, she discovered that he was a 
university graduate, who like a lot of young men in Delta, had been

forced to take a job far below his qualifications.(191

Furthermore, Habila conveys the theme of anxiety associated with insecurity in his novel under study. Sample 3 contains questions asked in quick succession by Mr Floode whose wife is held hostage by kidnappers. The author deploys the questions stylistically to convey Mr. Floode's anxiety over his abducted wife, Isabel. As earlier stated, Isabel is abducted to avenge the betrayal of her husband's driver.

Habila also utilizes interrogative sentences in samples 4 and 5 to convey the themes of displacement, hardship and sorrow in the novel. Chief Ibiram and members of his extended family are forced out of their ancestral family compound to relocate out of frustration. Question 4 above is directed to Chief Ibiram by Zaq, the newspaper reporter, to inquire whether his displaced family members are happy in their new location. Chief Ibiram responds with question 5. With the response, Habila depicts the hardship, anguish and sorrow to which the displaced people in Niger delta are subjected.

In sample 6, the literary artist reiterates and condemns the activities of the soldiers deployed by the government to Niger Delta to maintain peace. Instead of protecting the people, the soldiers take laws into their hands to inflict more injuries on them. Major, a character in the novel, vividly describes the condition of Irikefe village after it has been attacked and razed down by the soldiers, saying:

Irikefe is now mostly ashes and rubble, bombed by the gun helicopter over there. Not a hut is left standing... (157)

At that juncture, Rufus, the newspaper reporter, inquires about the inhabitants of Irikefe in sample 6. In response, Major emphasizes that as a war zone a lot of casualties are expected among the villagers.

\subsection{Exclamatory Sentences}

A sentence that expresses some strong or sudden feeling is called an exclamatory sentence (Murthy 236). This could be feeling of fear, shock, anxiety, and joy among others.

1. THEY ARE HERE! The soldiers are here! (12)

2. In the distance a woman wailed at the top of her voice, calling to

God over and over: Tamuno! Tamuno! (12)

In the exclamatory sentences above, the author reiterates the state of unrest and mental agony associated with the Niger Delta region due to the incessant clashes between the soldiers and militants.

\section{Conclusion}

In this paper, it has been established that the processes of crude oil extraction in the Niger Delta has resulted in devastating effects of ecological degradation, which has subjected the people of the region to serious crises, ranging from environmental pollution, poverty, hunger, diseases to death. It is also stated that Helon Habila has deployed the mood system as a language tool in his novel, Oil on Water, to create awareness on the Niger Delta crises. He calls on the Nigerian government and the oil companies operating in the area to address the crises with all seriousness, to avert the impending ecological danger, and proffer permanent solutions to the crises. To a large extent, these could be achieved if the government and oil companies give the Niger delta and the people priority attention, in terms of human and infrastructural developments.

\section{References}

Chomsky, N. (1965). Aspect of the theory of syntax. M.I.T Press: London.

Habila, H. (2010). Oil on water. Harrish Hamilton: London.

Halliday, M. (1970). Exploration in the function of language/teaching. Edward Alnold: London.

Heffernan, A. W. and John, L. (1986). Writing a college handbook. Norton and Company: New York.

Murthy, J. (2007). Contemporary english grammar. Book Palace: New Delhi.

Osunkenta, G. O. Education, literature and national development. Lekan.

Oyeleye (2004). Language and discourse in society. Hope Publications Ltd. 209-27.

Widdowson, H. G. (1975). Stylistics and teaching of the literature. Longman: Essex.

Yanson, K. (1987). An Introduction to Literary Stylistics. Pacific Publisher: Obosi. 